\title{
DEPRESSION, ANXIETY AND STRESS- A CROSS-SECTIONAL STUDY IN A COHORT OF SCHOOL STUDENTS FROM SOUTH INDIA
}

\author{
Shankar Kanagasabapathy1, Satya Raj ${ }^{2}$
}

1 Professor, Department of Community Medicine, Meenakshi Medical College and Research Institute, Kancheepuram, Tamilnadu. ${ }^{2}$ Associate Professor, Unit of Child and Adolescent Psychiatry, Department of Psychiatry, Christian Medical College, Vellore, Tamilnadu.

\section{ABSTRACT}

\section{BACKGROUND}

The theme for the 2017 World Health Day campaign is Depression. WHO estimates that a total of 300 million people living in this world suffer from depression. Similar is the case of anxiety which affects 264 million or $3.6 \%$ of the global population. Depression, Anxiety and Stress afflict a large extent of the student population, especially during their higher secondary level when they actually need to perform the best. Frequent policy changes by the Government on school curriculum and admission to Professional colleges like the recent National Eligibility and Entrance Examination (NEET) also adds on to this. In states like Tamilnadu, there is widespread criticism that it may be disadvantageous for students coming from rural areas and those studying in State board schools.

\section{MATERIALS AND METHODS}

Random sample of 320 consenting students studying in science groups in Grade 11 and 12 in Higher/Senior secondary schools in Kancheepuram district were enrolled in this study. DASS-42 (Depression, Anxiety and Stress Scale) was used to measure their Depression, Anxiety and Stress levels. Data was tabulated and analysed using SPSS-16.

\section{RESULTS}

The mean DASS-42 scores in the three domains of Depression, Anxiety and Stress were 13.18, 12.81 and 17.17 respectively. This corresponds to mild Depression, moderate Anxiety and mild Stress. The mean scores for Depression, Anxiety and Stress of male students were 13.54, 13.02 and 18.03 respectively, and the female students had scores of $12.68,12.52$ and 16.01 respectively. This sex difference was found to be statistically significant $(\mathrm{p}<.01)$. Similarly, students who resided in urban areas had significantly ( $\mathrm{p}$ $<.01)$ more levels of Depression, Anxiety and Stress than those students who resided in rural areas. Their school board did not make a significant difference in their anxiety and stress levels.

\section{CONCLUSION}

This study observed mild-to-moderate prevalence of Depression, Anxiety and Stress among the study population. Students are already under pressure from their parents, peers and society to excel academically. Added to this, the frequently changing policies of the government regarding curriculum, assessment and entry to higher education courses may take a severe toll on their health.

\section{KEYWORDS}

Depression, Anxiety, Stress, DASS-42.

HOW TO CITE THIS ARTICLE: Kanagasabapathy S, Raj S. Depression, anxiety and stress- a cross-sectional study in a cohort of school students from South India. J. Evolution Med. Dent. Sci. 2017;6(41):3205-3208, DOI: 10.14260/Jemds/2017/694

\section{BACKGROUND}

The world health day falls on April $7^{\text {th }}$ of each year. The theme for the 2017 World Health Day campaign is depression. WHO estimates that a total of 300 million people living in this world suffer from depression. Similar is the case of anxiety, which affects 264 million or $3.6 \%$ of the global population. A similar number of individuals suffer from a range of anxiety disorders. Nearly half of the individuals affected live in the South-East Asian region and the Western pacific, which includes India.

Financial or Other, Competing Interest: None.

Submission 07-04-2017, Peer Review 09-05-2017,

Acceptance 15-05-2017, Published 22-05-2017.

Corresponding Author:

Dr. Shankar Kanagasabapathy,

Department of Community Medicine,

Meenakshi Medical College and

Research Institute,

Enathur, Kancheepuram-631552,

Tamilnadu, India.

E-mail: shankarsalem@yahoo.com

DOI: $10.14260 /$ jemds $/ 2017 / 694$

(c) $(7)(\$$
Depression is more common in females than males, and there has been an increase of $18.4 \%$ in the prevalence of depression between 2005 and 2015.(1) The consequence of this on Human health is huge. With the advent of DALY (Disability Adjusted Life Years), the importance of mental illness has significantly increased amongst the Global burden of diseases. Depression is ranked by WHO as the single largest contributor to global disability with $7.5 \%$ of years lived with disability as on 2015. Similarly, anxiety disorders contribute $3.4 \%$ of all years lived with disability.(1)

Studies show that depression and anxiety afflict a large extent of the student population.(2,3) These illness among student population can significantly impair their scholastic performance. There is documented evidence to show that anxiety and stress during education can cause impairment in cognition.(4) This in turn might cause problems in personal and academic arenas leading to school dropout, poor academic performance and can also increase the risk of suicide.(5) There have been documented studies that proved beyond doubt that the prevalence of anxiety among school students was due to parental pressure for high academic achievement.(6) 
Exposure to these stressors can lead to many problems. If he or she is exposed to chronic stress, it is likely to manifest as physical and mental illness.(7) Studies have also shown that stressors on its own do not produce anxiety, depression, etc. Only when it interacts with a person's perception and the subsequent reaction to these stressors cause major problems. ${ }^{(8)}$

The Indian system of education by itself has been considered by many to be very stressful for the student community. Students, especially those studying at the higher secondary level in India face different problems. Unlike many other countries across the globe, there is no uniform national board for all students across India and the country is moving towards a single nationwide entrance examination for most college courses like that of NEET (National Eligibility cum Entrance Examination) for admission to undergraduate medicine (MBBS) course.

Many states like Tamilnadu have their own board, which formulates the curriculum for the students studying in their respective states. Securing an admission into a professional course is the dream of many school students and their parents. At the time this study was conducted, there was still an uncertainty in the state of Tamilnadu regarding the NEET for admission to undergraduate medicine course. Many parents wish to enrol their children in a school that follows the state board curriculum, so as to make it easier for them to secure admission in a medical college in Tamilnadu. Because of legal and other issues beyond their control, the higher secondary students in Tamilnadu are not yet sure whether they need to clear the national level examination to enter into a medical college or they would be admitted to the course based on their performance in the state board examination conducted after their $12^{\text {th }}$ standard as was being done till academic year 2016 - 2017. This uncertainty itself may be the cause for stress amongst the student community at the higher secondary level. The students who are studying in the CBSE (Central Board of Secondary Education) schools are more likely to have an advantage here. Moreover, there is fierce competition among students at the higher secondary level, for the limited seats available in most professional colleges in the country. Added to this, the pressure exerted by the parents over the students to perform well also has a significant effect on the mental health of the students.

As things stand, there is widespread criticism in the state of Tamilnadu and also in other states that are opposed to a nationwide entrance test to professional courses. The politicians and certain section of the public feel that nationwide examinations like NEET may be disadvantageous for students coming from rural areas and those studying in state board schools. Hence, this study was planned to be conducted among students who had taken up science group in their higher secondary classes, i.e. Grade 11 and 12 in Tamilnadu. The objective was to measure their Depression, Anxiety and Stress levels, and to compare these levels with certain socio-demographic variables like sex, place of residence and school board.

\section{MATERIALS AND METHODS}

This cross-sectional study was done in Kancheepuram district, situated in the North-Eastern part in the state of Tamilnadu. Historically, Kancheepuram has been a centre of learning. For administrative purposes, this district is divided into 3 revenue divisions, namely Kancheepuram, Chengalpattu and Maduranthagam and 13 taluks. This study was done in schools situated in Kancheepuram revenue division. All the eligible Higher/Senior secondary schools in the study area were approached for this study. Among the schools that gave permission to do conduct the study, two schools that followed the CBSE (Central Board of Secondary Education) curriculum and two schools that followed the Tamilnadu state board curriculum were selected at random.

Assuming $25 \%$ as the most probable prevalence of Depression, Anxiety and Stress among the student population with a limit of accuracy of $20 \%$ of the prevalence and with $\mathrm{Z}$ value of 1.96 , the sample size calculated was 288 . About $10 \%$ of the sample size was added to take care of any absentees, and last minute refusals to participate in the study. Hence, the total sample size arrived for the study was 320 .

Since this study was planned to be conducted among students studying in Higher/Senior secondary classes, especially those studying in the science groups, the name list of all the students who had taken up science group in their $11^{\text {th }}$ and $12^{\text {th }}$ grade was obtained from all the four schools. Since all the schools had more or less similar number of students studying in science groups, a simple random sampling methodology was followed. The names were arranged in an alphabetical order and using the simple random sampling technique a total of 320 students were chosen. Informed consent was obtained from the principal of each of those schools and also from all the students who were willing to participate in the study. Only students who gave the informed consent were enrolled in the study. Students who were not willing to participate in the study and those who had previous known psychiatric morbidity were excluded from this study. In consultation with the school administration, a convenient date and time to conduct the study was selected. Care was taken so that the students were not put under any hardship, by the way of losing classes or they were subjected to some diversion that would hinder their study time at school. The whole study process was conducted during their free hours and to maintain privacy the name of the student or the school was not required to be mentioned anywhere in the questionnaire.

On the pre-appointed day, all students were made to assemble at a common place in their respective schools and were administered the study instrument by the investigator. The study instrument consisted of a brief questionnaire that elicited their background details and the Depression, Anxiety and Stress Scale (DASS-42). The DASS consists of three selfreport scales that are designed to measure the negative emotional states in human beings like depression, anxiety and stress. ${ }^{(9)}$ For each item, the subjects are to rate in a fourpoint Likert scale; to the extent they have experienced the state in the past week. The corresponding scores for depression, anxiety and stress are obtained by adding the scores of the relevant items.(10) There are many studies that have proved the reliability and validity of this instrument in measuring Depression, Anxiety and Stress.(11,12) A short 21 item version of this questionnaire is also available. The DASS instrument had been used earlier among school and college students across the globe.(13,14) The data was analysed using statistical package for social sciences, version 16 (SPSS-16). Student's t-test was used to compare the means and to ascertain the level of significance. 


\section{RESULTS}

A total of 320 students took part in this study. Out of this cohort of students, 184 (57.5\%) were males and the rest were females. Similarly, about 155 students were residing in rural areas and 150 students were studying in schools that followed the CBSE curriculum. Details are given in Table 1.

\begin{tabular}{|c|c|c|c|}
\hline $\begin{array}{c}\text { Selected Socio-Demographic } \\
\text { Characteristics }\end{array}$ & $\begin{array}{c}\text { Number of } \\
\text { Students }\end{array}$ & Percentage \\
\hline \multirow{2}{*}{ Sex } & Male & 184 & $(57.5 \%)$ \\
\cline { 2 - 4 } & Female & 136 & $(42.5 \%)$ \\
\hline \multirow{2}{*}{$\begin{array}{c}\text { Place of } \\
\text { Residence }\end{array}$} & Rural & 155 & $(48.4 \%)$ \\
\cline { 2 - 4 } School Board & Urban & 165 & $(51.6 \%)$ \\
\cline { 2 - 4 } & State Board & 150 & $(46.9 \%)$ \\
\hline \multirow{3}{|c|}{$\begin{array}{c}\text { Table 1. Table shows the Total Number of Students } \\
\text { belonging to the two Sexes, their Place of Residence, } \\
\text { and the Board to which their School is Affiliated To }\end{array}$} \\
\hline
\end{tabular}

The mean scores for Depression, Anxiety and Stress in DASS-42 were 13.18, 12.81 and 17.17 respectively. Minimum score in Depression was 4 and the maximum was 20 . Minimum and maximum scores of Anxiety and Stress are given in table. Details are given in Table 2.

\begin{tabular}{|c|c|c|c|c|}
\hline $\begin{array}{c}\text { Domains } \\
\text { Measured }\end{array}$ & Minimum & Maximum & Mean & $\begin{array}{c}\text { Standard } \\
\text { Deviation }\end{array}$ \\
\hline Depression & 4 & 20 & 13.18 & 1.61 \\
\hline Anxiety & 3 & 16 & 12.81 & 1.67 \\
\hline Stress & 5 & 24 & 17.17 & 1.88 \\
\hline
\end{tabular}

Table 2. Table shows the Scores obtained by the Students in the three dimensions, Depression, Anxiety and Stress as measured by the DASS-42

The mean score for Depression was compared with selected socio-demographic variables like, sex, place of residence and the curriculum followed in the corresponding school. It was observed that the mean score of depression was 13.54 in males and lesser in females. This difference was found to be statistically significant. Similarly, the score for depression was higher among students who were residing in an urban area $(13.56 \%)$ than those who came from rural areas. Statistical significance was observed in this difference too. Similarly, there was a statistically significant difference in the level of depression among students who studied in CBSE and state Board. Details are given in Table 3.

\begin{tabular}{|c|c|c|c|c|}
\hline \multicolumn{2}{|c|}{$\begin{array}{l}\text { Selected Socio- } \\
\text { Demographic } \\
\text { Characteristics }\end{array}$} & \begin{tabular}{|} 
Mean Score \\
for \\
Depression in \\
DASS-42 \\
\end{tabular} & $\begin{array}{l}\text { Standard } \\
\text { Deviation }\end{array}$ & P-Value \\
\hline \multirow{2}{*}{ Sex } & Male & 13.54 & 1.65 & \multirow{2}{*}{$\begin{array}{c}<.001 \\
(t=4.888, \\
d f=318)\end{array}$} \\
\hline & Female & 12.68 & 1.41 & \\
\hline \multirow{2}{*}{$\begin{array}{c}\text { Place of } \\
\text { Residence }\end{array}$} & Rural & 12.77 & 1.60 & \multirow{2}{*}{$\begin{array}{c}<.001 \\
(\mathrm{t}=4.554, \\
\mathrm{df}=318)\end{array}$} \\
\hline & Urban & 13.56 & 1.52 & \\
\hline \multirow[b]{2}{*}{ School } & CBSE & 12.87 & 1.48 & \multirow{2}{*}{$\begin{array}{c}.001(\mathrm{t}=- \\
3.301 \\
\mathrm{df}=318)\end{array}$} \\
\hline & $\begin{array}{l}\text { State } \\
\text { Board }\end{array}$ & 13.45 & 1.67 & \\
\hline
\end{tabular}

Table 3. Table shows the Difference in the Level of Depression among the School Students based on their Sex, Place of Residence and School Board

The mean score for anxiety among male students was 13.02 and female students were 12.5. This difference was found to be statistically significant. Similarly, the students who were residing in urban areas had more anxiety than students residing in rural areas. This was also statistically significant, whereas there was no significant difference in the level of anxiety among students studying in State Board or Central Board schools. Details are given in Table 4.

\begin{tabular}{|c|c|c|c|c|}
\hline \multicolumn{2}{|c|}{$\begin{array}{l}\text { Selected Socio- } \\
\text { Demographic } \\
\text { Characteristics }\end{array}$} & \begin{tabular}{|c|} 
Mean Score \\
for Anxiety in \\
DASS-42 \\
\end{tabular} & $\begin{array}{l}\text { Standard } \\
\text { Deviation }\end{array}$ & P-Value \\
\hline \multirow[b]{2}{*}{ Sex } & Male & 13.02 & 1.66 & \multirow{2}{*}{$\begin{array}{c}0.008 \\
(t=2.675 \\
d f=318)\end{array}$} \\
\hline & Female & 12.52 & 1.64 & \\
\hline \multirow{2}{*}{$\begin{array}{c}\text { Place of } \\
\text { Residence }\end{array}$} & Rural & 12.42 & 1.39 & \multirow{2}{*}{$\begin{array}{c}<.001 \\
(\mathrm{t}=4.157 \\
\mathrm{df}=318)\end{array}$} \\
\hline & Urban & 13.17 & 1.82 & \\
\hline \multirow[b]{2}{*}{ School } & CBSE & 12.93 & 1.82 & \multirow{2}{*}{$\begin{array}{c}0.238 \\
(\mathrm{t}=1.182, \\
\mathrm{df}=318)\end{array}$} \\
\hline & $\begin{array}{l}\text { State } \\
\text { Board }\end{array}$ & 12.70 & 1.52 & \\
\hline
\end{tabular}

Table 4. Table shows the Difference in the Level of Anxiety among the School Students, based on their Gender, Place of Residence and School Board

The level of stress as assessed by DASS-42 showed a similar picture. The mean score for stress was 18.03 among males and 16.01 among female students. This difference was found to be statistically significant. When the place of residence was taken into consideration, it was observed that the level of stress was more among urban residents than rural residents. This difference was found to be statistically significant. There was no significant difference in the level of stress between students studying in State Board schools and those from the Central Board schools. Details are given in Table 5 .

\begin{tabular}{|c|c|c|c|c|}
\hline \multicolumn{2}{|c|}{$\begin{array}{c}\text { Selected Socio- } \\
\text { Demographic } \\
\text { Characteristics }\end{array}$} & $\begin{array}{c}\text { Mean Score } \\
\text { for Stress in } \\
\text { DASS-42 } \\
\end{array}$ & $\begin{array}{l}\text { Standard } \\
\text { Deviation }\end{array}$ & P-Value \\
\hline \multirow{2}{*}{ Sex } & Male & 18.03 & 1.99 & \multirow{2}{*}{$\begin{array}{c}<.001 \\
(t=11.104, \\
d f=318)\end{array}$} \\
\hline & Female & 16.01 & 0.81 & \\
\hline \multirow{2}{*}{$\begin{array}{c}\text { Place of } \\
\text { Residence }\end{array}$} & Rural & 16.16 & 1.18 & \multirow{2}{*}{$\begin{array}{c}<.001 \\
(t=10.868 \\
d f=318)\end{array}$} \\
\hline & Urban & 18.12 & 1.93 & \\
\hline \multirow[b]{2}{*}{ School } & CBSE & 17.28 & 2.42 & \multirow{2}{*}{$\begin{array}{c}0.336 \\
(t=.964 \\
d f=318)\end{array}$} \\
\hline & \begin{tabular}{|c|} 
State \\
Board \\
\end{tabular} & 17.08 & 1.24 & \\
\hline
\end{tabular}

Table 5. Table shows the Difference in the Level of Stress among the School Students, Based on their Sex, Place of Residence and School Board

\section{DISCUSSION}

This study that was done among 320 students studying in Grade 11 and 12 in Higher/Senior secondary schools, highlights the importance of mental well-being during the formative years. The mean scores of depression, anxiety and stress was $13.18,12.81$ and 17.17 respectively. This corresponds to mild level of depression, moderate level of anxiety and mild level of stress as per the scoring protocol of DASS-42. A similar study done by Sanjiv K. Bhasin et al also found significantly higher levels Depression, Anxiety and Stress among school students.(15) That study compared the level of Depression, Anxiety and stress among $9^{\text {th }}$ and $10^{\text {th }}$ grade students versus $11^{\text {th }}$ and $12^{\text {th }}$ grade students. They found higher prevalence among the students studying in the 
higher grades.(15) Whereas, the present study was done only among students studying in the $11^{\text {th }}$ and $12^{\text {th }}$ grade. The higher prevalence of Depression, Anxiety and Stress at the Higher/Senior secondary level may be due to academic pressure at that level and also the uncertainty about their academic future.

This study also found a significant difference in the Depression, Anxiety and Stress levels among the male and the female students. The levels of all these three domains were higher in male students than female students. Few studies done abroad have observed that anxiety levels were more common in female students than the males.(16) The findings in the current study could be due to social pressure that is exerted on male students to perform well in academics and advance to a cushy career, whereas the same level of pressure may not be exerted on the female students, especially in rural areas. Many parents residing in rural areas in India want their female children to study, just enough to get them equipped for marriage. A study done among high school students in Kolkata also observed that levels of anxiety was higher in male students than female students.(17)

The place of residence of the students also impacted their mental wellbeing. Students, who basically resided in urban areas had higher levels of Depression, Anxiety and Stress compared to those who had their residence in a rural area. There were not many studies that compared the place of residence and mental morbidity. In another study done in North India, the authors observed that the level of anxiety was less among the students from high and low socioeconomic classes when compared to those belonging to middle socio-economic class.(17)

Yet another study done among professional college students in India reported higher levels of stress among female students.(18) They also observed that participants residing in urban areas had more stress than those from rural areas. The present study observed higher level of stress among male students than female students and also the stress levels were more among students residing in urban areas. As already discussed above, the difference in the level of stress among the two sexes could be due to the difference in the societal and parental expectations from a male and female child.

\section{CONCLUSION}

This study that was done among a small population of students in Tamilnadu clearly highlighted the mental health issues that inflict our student community. Especially when there is a policy change by the government every few years, that creates a lot of uncertainty about their future. This uncertainty, combined with parental and societal pressure precipitates Depression, Anxiety and Stress. The government's policies regarding higher education should address these issues. Even if there is need to do a radical reform in our educational system, it has to be implemented in a phased manner, giving ample time for the students who are used to a particular system to prepare for change and to adapt to the new norm.

\section{REFERENCES}

[1] Depression and other common mental disorders: global health estimates. Geneva: World Health Organization 2017. Licence: CC BY-NC-SA 3.0 IGO.
[2] Andrews B, Wilding JM. The relation of depression and anxiety to life-stress and achievement in students. Br J Psychol 2004;95(pt 4):509-21.

[3] Emslie GJ, Mayes TL, Ruberu M. Continuation and maintenance therapy of early-onset major depressive disorder. Paediatr Drugs 2005;7(4):203-17.

[4] Vitaliano PP, Russo J, Carr JE, et al. Medical school pressures and their relationship to anxiety. J Nerv Ment Dis 1984;172(12):730-6.

[5] Sharif F, Armitage P. The effect of psychological and educational counselling in reducing anxiety in nursing students. J Psychiatr Ment Health Nurs 2004;11(4):386-92.

[6] Deb S. A study on the negative effects of academic stress. Paper presented at the International Seminar on Learning and Motivation, Kedah Darul Aman, Malaysia. 2001.

[7] Auerbach MS, Grambling SE. Stress management psychological foundations USA Prentice- Hall, Inc 1998.

[8] Shirom A. Students's stress. Higher Education 1986;15(6):667-76.

[9] Lovibond SH, Lovibond PF. Manual for the depression anxiety stress scales. $2^{\text {nd }}$ edn. Sydney: Psychology Foundation 1995.

[10] Lovibond SH, Lovibond PF. Overview of the DASS and its uses. Available online at: www2.psy.unsw.edu.au/Groups/ Dass/over.htm. Last accessed: January 05, 2010.

[11] Henry JD, Crawford JR. The short-form version of the Depression Anxiety Stress Scales (DASS-21): construct validity and normative data in a large non-clinical sample. Br J Clin Psychol 2005;44(Pt 2):227-239.

[12] Nieuwenhuijsen K, deBoer AGEM, Verbeek J, et al. The Depression Anxiety Stress Scales (DASS): detecting anxiety disorder and depression in employees absent from work because of mental health problems. Occup Environ Med 2003;60(Suppl 1):i77-i82.

[13] Bayram N, Bilgel $N$. The prevalence and sociodemographic correlations of depression, anxiety and stress among a group of university students. Soc Psychiatry Psychiatr Epidemiol 2008;43(8):667-72.

[14] Vaidya PM, Mulgaonkar KP. Prevalence of depression anxiety \& stress in undergraduate medical students \& its co relation with their academic performance. Indian J Occu Therapy 2007;39(1):7-10.

[15] Bhasin SK, Sharma R, Saini NK. Depression, anxiety and stress among adolescent students belonging to affluent families: a school-based study. Indian Journal of Pediatrics 2010;77(2):161-165.

[16] Costello EJ, Mustillo S, Erkanli A, et al. Prevalence and development of psychiatric disorders in childhood and adolescence. Arch Gen Psychiatry 2003;60(8):837-44.

[17] Deb S, Chatterjee P, Walsh K. Anxiety amongst high school students in India. Australian Journal of Educational \& Developmental Psychology 2010;10: 18-31.

[18] Waghachavare VB, Dhumale GB, Kadam YR, et al. A study of stress among students of professional colleges from an urban area in India. Sultan Qaboos University Med J 2013;13(3):429-36. 